\title{
Renewable Energy Producers' Strategies in the Visegrád Group Countries
}

\author{
Adam Sulich ${ }^{1, *(1)}$ and Letycja Sołoducho-Pelc ${ }^{2}$ (I) \\ 1 Department of Advanced Research in Management, Faculty of Management, Wroclaw University of \\ Economics and Business, 53-345 Wroclaw, Poland \\ 2 Strategic Management Department, Faculty of Management, Wroclaw University of Economics and Business, \\ 53-345 Wroclaw, Poland; letycja.soloducho-pelc@ue.wroc.pl \\ * Correspondence: adam.sulich@ue.wroc.pl
}

check for updates

Citation: Sulich, A.; Sołoducho-Pelc, L. Renewable Energy Producers' Strategies in the Visegrád Group Countries. Energies 2021, 14, 3048. https://doi.org/10.3390/en14113048

Academic Editors: Akhtar Kalam and Vincenzo Bianco

Received: 19 April 2021

Accepted: 21 May 2021

Published: 24 May 2021

Publisher's Note: MDPI stays neutral with regard to jurisdictional claims in published maps and institutional affiliations.

Copyright: (c) 2021 by the authors. Licensee MDPI, Basel, Switzerland. This article is an open access article distributed under the terms and conditions of the Creative Commons Attribution (CC BY) license (https:/ / creativecommons.org/licenses/by/ $4.0 /)$.
Abstract: Companies that belong to the energy sector can use Sustainable Development Goals (SDGs) for their strategies and diversify electrical energy production with reverence to the natural environment. This article aims to analyze sustainability strategy types among the Visegrád Group (V4) countries' energy producers, who decided to generate electrical energy from the renewable resources. This research uses an inductive inference approach supported by a literature study and deductive reasoning supported by a statistical reference method. The main finding is that the energy producers from the V4 group have a common direction of evolution in their strategies. This change is based on a growing share of renewable energy sources to achieve environmental excellence strategies. The lack of renewable energy sector organizations' strategies translates into disappointment with the goals pursued by these organizations. The significance of this study lies in an explanation of how sustainability strategies compare at a firm and country-level in a proposed classification. The analysis can open future research areas to examine development of strategies in the renewable energy sector.

Keywords: Hellwig's method; sustainability strategies; sustainable development; Visegrád Group; sustainable strategic management; the renewable energy sector

\section{Introduction}

The energy sector worldwide is crucial for the economic development. Electrical energy producers are involved in the economy because energy sources impact prices of energy goods and services [1]. Future development strategies apply to all organizations, especially those that counteract environmental pollution and climate change [2]. There are organizations that implement sustainable strategies [3] towards sustainable development (SD) despite their main activities [4]. Therefore, increasing investment in Renewable Energy Sources (RES) as a part of strategy can contribute to achieving chosen Sustainable Development Goals (SDGs) among electrical energy producers [5] in different countries [6]. SDGs can also set the course for sustainable strategies in electrical energy sector companies [7]. However, electrical energy production is the main cause of climate change [8] and accounts for the majority of global greenhouse emissions [9]. Any future effort to achieve the SDGs will thus generate demand for more energy $[10,11]$. The Renewable Energy (RE) sector is the basis for green technology investments [12] and together with the nonrenewable energy sector, it creates the backbone for domestic economy development [13]. There are multiple examples of technology innovations in biomass, wind, solar and hydro power generation worldwide [14]. Achieving SD through the use of RES to mitigate the unfavorable effects of climate change can generate direct and indirect economic benefits [15]. Therefore, some energy producers have decided to generate electrical energy from RES [16]. The importance of energy sector companies is indisputable, and their efforts towards achieving SDGs serve as a model for other organizations in other sectors of the economy $[17,18]$. Successful implementation of the chosen sustainability strategy level among renewable electrical 
energy suppliers can influence the domestic economy. On the other hand, if there is a lack of strategy it translates into disappointment with the SDGs pursued by these organizations.

The aim of the paper is to analyze types of sustainability strategies formulated among the Visegrád Group (V4) energy producers who decided to produce electrical energy from RES [19-22]. Inspiration were strategies derived from the RE sector [5] and discussions related to consistency of management style [23]. In this paper, we consider nuclear energy as clean energy but not renewable. The Visegrád Group is a political group formed by four central European countries Czechia (CZ), Poland (PL), Slovakia (SK) and Hungary (HU), which all belong to the European Union (EU) [24]. An important common feature of the V4 countries is the fact that energy transformation in these countries began later than in other EU member states [25].

With this purpose, our work is structured as follows. In the first place, the paper develops a theoretical framework within a literature review that covers the main subjects: sustainable development, sustainability strategies and related terms. Then, a brief description of the electrical energy production sector together with RE sector development conditions in the V4 is discussed. In this part, a SWOT analysis (Strengths, Weaknesses, Opportunities, and Threats) of the Visegrád Group countries RE sector is presented. In the third part of this paper, the materials and methods are described along with the results and discussion. In the conclusions, comprehension of strategies and evolution-based classifications are discussed. This classification constitutes the authors' theoretical and practical contribution to the science. The presented work develops a quantitative empirical study comprising four different countries' perspectives for the strategies in the RE sector among their main energy producers. The study is based on business data and opens a new level of cross-border comparisons among energy producers. The paper ends with conclusions and possible future study proposals, along with listed limitations and practical business, environmental and social implications.

\section{Literature Review}

In this paper, the authors focus mostly on the RE sector and its development conditions in the Visegrád Group without describing the whole energy production sector in detail in relation to other energy sources and technologies. The scope of the literature review is renewable electrical energy generation development conditions and sustainability strategies.

\subsection{Sustainable Development and Related Terms}

$\mathrm{SD}$ is an approach to build a common future through such human activity which meets the "needs of the present and future generations" [26,27]. SD is also a concept of quality of life with an unlimited time horizon because its assumptions are based on natural laws, are timeless and universal $[17,18,28,29]$. The concept of SD is a counterbalance to the "brown economy", which is based on fossil fuels and has resulted in environmental degradation [28]. The "brown economy" is known for its negative environmental impact due to the inability to overcome the current ecological crisis. The energy demand is growing, associated with the growing demand for natural resources and resulting in an increasing amount of harmful waste. The search for solutions to reconcile growing energy needs with environmental resources and protection is still ongoing [29].

SD approaches differ between countries, regions and organizations, but for all of them achieving a balance between output and input within the natural environment is a priority. Thus, SD is based on the ability to use renewable resources, reduce pollution and avoid reduction of nonrenewable assets [12]. For many years, natural resources have been exploited and, as a result, environmental problems have become common global issues. Modern economic growth is driven mainly by the exploitation of natural resources that results in environmental degradation. The energy sector and related industries struggle to achieve SDGs and, paradoxically, their activities are in opposition to the SD assumptions. 
The world community has adopted SD as a concept based on the three defined pillars of sustainability: environment, economy and society [30]. These three aspects are essential and have been developed to be more applicable to business policy and strategy. However, elements of the SD idea [31] are related to business development issues within the focus of Sustainable Strategic Management (SSM). Therefore, the idea of Environmental Sustainability (ES) emerged from the consolidation of environment and business sustainability [32]. ES assumes maintaining the business integrity and ecological balance of the natural environment system [33]. Such a balance is possible, assuming that people consume natural resources at a rate and with amounts that complement each other [12]. ES depends on the maintenance of natural capital to meet people's current needs, while protecting raw materials for future generations [34]. On the other hand, ES assumes that waste can be stored as a future resource and be used when the proper technology is developed [35]. Therefore, the cleaning and removal processes for environmental services must be maintained and improved in the future [12,34]. There are other dimensions of $\mathrm{SD}$, including economic and social systems. Economic Sustainability is the capacity to operate at a defined economic level [36,37], while Social Sustainability (SS) is the ability of a society [38] to perform at a higher level of wellbeing [13,39]. The evolution of strategic management for sustainable development incorporates strategic perspectives of corporate sustainability management and introduces [40] sustainable strategic management (SSM). SSM connects all possible approaches to SD, defined or indicated by the three SD pillars [4].

The need to achieve SDGs, build a balance with the environment and strengthen the organization's competitiveness led to the synergy of sustainable development and SSM strategy [27]. The concept was derived from ecological trends such as the influence of business on the natural environment, protection of natural resources, social trends and business management and strategy [41]. SSM assumes strategically importance processes for the organization that meet social responsibility criteria, harmony with the cycles of nature and economic competitiveness [42]. Combination of the economic and environmental goals included in SSM leads organizations towards sustainable competitive advantage [43].

\subsection{Sustainability Strategies}

Lack of SD achievement can be induced by nonstrategic approach in organizations. Therefore, the main problem is to transfer SDG ideas and assumptions into SSM and business practice [44]. Additionally, many sustainability strategies (in scientific publications also known as 'sustainable strategies') have been developed and described to solve environmental problems, but many have not been implemented [5]. The problem with SSM is implementation of strategies consistent with the type industry and natural environment conditions [23]. Although the idea of SD is popular with politicians, business leaders, entrepreneurs and societies, its implementation causes many problems in business practice [45]. Therefore, there is the tendency to use the same strategic approaches in many different economic sectors. The implementation of SSM faces various barriers, but the most critical problem is related to the process of changing the organization's management [27] and management style, and is associated with consistency of strategy type [44,46]. According to this article, strategy-type consistency means internal and external consistency between an organization's activities, management style, decision making, culture, the values of the organization and the implemented strategy. Difficulties in maintaining consistency result from management in a changing environment, where management is constantly transformed under the influence of a large number of different factors important to competitive advantage [47]. It can be assumed that strategy type consistency is the capability to balance economic, social and environmental dimensions combined with industry type. This balance should facilitate the strategy's implementation by ensuring management's harmonization with the strategy [48]. The evolution of the SSM approach has led to the recognition that environmental and social performance [42,49] is as important as an organization's economic performance [50]. 
A sustainability strategy is not limited to the planning of future activities [51]. Furthermore, strategic initiatives in organizations should be broader in many areas [52]. "Sustainable organizations demonstrate successful long-term performance aimed the restrictions imposed by economic, social, and environmental systems by developing a strategy that sustainably generates and captures value into the future" [53]. Sustainability strategy increases the company's value and shapes the organization's success in the long term [54]. There is a need to indicate that for many production organizations reduction of pollution is a major problem because it is associated with the limitation of anthropopressure and is associated with production cycles. Reduction of pollutions emission is not enough to achieve a sustainable competitive advantage over the longer term [55].

There are different sustainability strategy levels among organizations and administrative units [27]. These sustainability [27,50] or sustainable [56] strategies are focused on the internal conditions of processes and compliance with external conditions (frame) formulated by government environmental management and SDGs implementation. Various types of sustainability strategies can be implemented within SSM (Figure 1). Sustainability strategies represent the different levels of the implementation of SDGs [57]. The levels range from basic environmental strategy, pro-ecological strategy, and finally the full engagement and consistency of management with SDG,s which is the green strategy [7]. Therefore, there are three types of sustainability strategies differentiated on coherence degree in SDG implementation concerning natural environment protection $[58,59]$. Based on this division, there are also fewer and more engaged organizations in the SDGs, which reflect their involvement in natural environment protection (represented by an arrow in Figure 1).

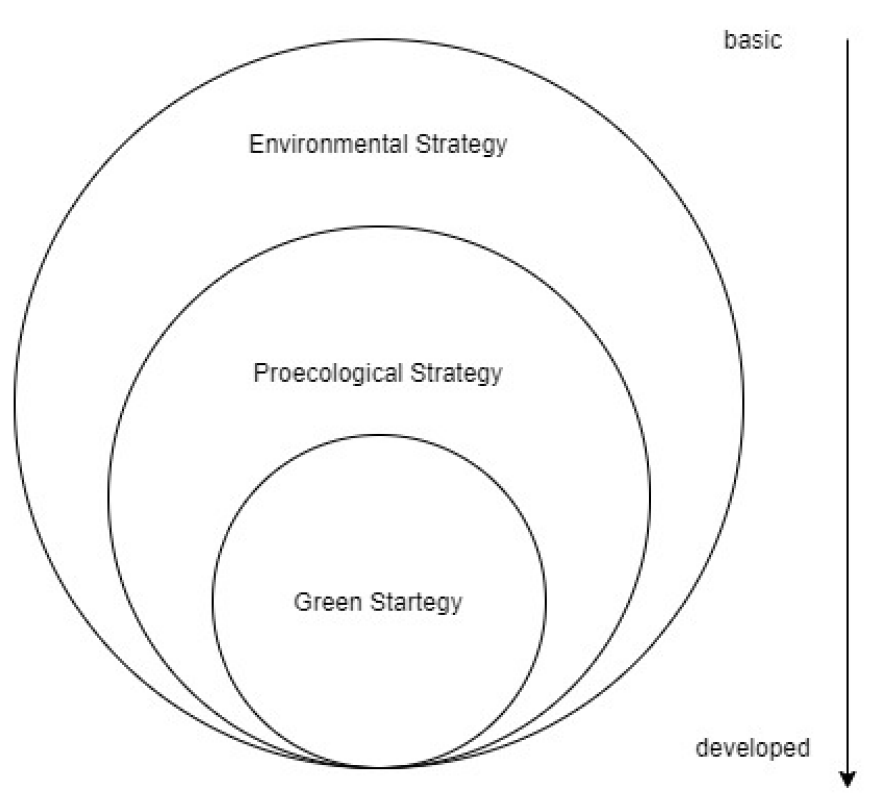

Figure 1. Relationship between sustainability strategies and management approaches. Source Authors' elaboration.

Environmental strategy is implemented by organizations that adapt to the environmental requirements legislated, and environment management formulated, by government [57]. It can be considered as a basic and minimum version of environmental measures that must be executed and met by organizations to avoid legal and financial consequences [60]. This type of strategy has obligatory implications and must be adopted by all organizations. The environmental strategy defines the organization's processes that impact the environment and points to environmentally-friendly practices [23]. In this strategy, organizations specify how they shape relations with the natural environment, and they adopt strategic attitudes [61]. The environmental strategy should be adapted to the circumstances of the 
organization's internal and external business environment conditions [23]. The environmental strategy can be used at a country level as well at the organization level, and it can be developed towards the next levels of sustainable strategies.

Proecological strategy concerns involvement in activities that go beyond the norms established by law and assumes the realization of chosen SDGs and treats them as sustainable strategic measures. Besides the obligatory law regulations, there are formal internal and external certificates, or industry standards, developed in this strategy level, which are not obligatory but voluntary [31]. Proecological strategy has a tactical nature and creates a connection between operational (environmental strategy) and strategic level (green strategy). Its purposes in organizations or in country-based strategies [42] are to enhance improvement of the natural environmental conditions or reduce anthropopressure (the negative impact of all human activity). On the other hand, if measurement of pro-ecological strategy implementation processes is not possible, there is no sustainable strategic management at this level $[17,49]$. However, if the development of a single government or organization's proecological strategy does not bring results, then action is required towards the next level of sustainability strategy [62].

The green strategy is most developed (Figure 1), which enhances quality of life by using new technological and organizational solutions and supporting green industry development. This type of strategy involves the almost maximum possible number of SDGs in the organization's activities. The practice of green strategy requires the involvement of top management and focusing their attention on the decision-making process related to the environment [43]. The choice of a green strategy is mainly due to internal factors, shaped by the commitment of the organization's management to consistency between management style and goals induced by the SD idea [23]. "A green strategy implies a proclivity to collaborate with stakeholders concerning environmental improvements, share information with competitors concerning environmental improvements, emphasize environmental improvements rather than short-term economic gains, and emphasize environmental improvements as a means of increasing earnings" [63].

\subsection{Electrical Energy Production Sector-Selected Characteristics}

Electrical energy has great importance for economic and social development and quality of life [64]. It is also assumed that energy demand will grow on a global scale in the near future [65]. Nowadays, for the majority of countries, energy production is based on coal combustion diversified by nuclear energy (recognized as clean energy) and some portion of RES [66]. The dominance of coal as a fuel has strategic political and socioeconomic importance [61,67]. The electric power industry burns coal, emits pollutants and produces solid wastes that damage the environment and cause large-scale changes to the landscape. Despite modification of the technology of generating electrical energy from coal, and improvement in processes related to reclaiming exhaust gases, coal combustion still harms the environment [68]. The majority of electricity producers are state-owned enterprises. These companies not only produce energy in their facilities but also distribute it because they possess the required infrastructure. Therefore, this economic sector harms the environment mainly due to electrical energy production processes and related direct hazards. This industry also shapes and changes the landscape during energy generation (renewable installations), transfer, distribution and retail of electricity. The transmission of electrical energy is managed by each country's transmission system operator [69]. Each operator within to the Visegrád Group belongs automatically [70] to the Central Europe Energy Partners, and they also belong to the European Union organization Union for the Coordination of Production and Transmission of Electricity (UCPTE).

Despite numerous declarations by politicians and leaders of business organizations involved in the energy sector, Sachs [71] drew attention to the problems and failures in implementing the idea of SD, especially in electric energy production practice [15]. On the other hand, when analyzing the possibilities of organizations such as energy producers, one can indicate the chances of implementing strategies that consider the needs of the 
natural environment. A beneficial development alternative for organizations operating in the energy sector is implementing strategies to reduce the negative impact on the natural environment. In this approach to the strategy, the most critical problems to be solved are pollution and waste generated during the energy production process and increasing power generation efficiency. Enterprises implementing environmentally-friendly strategies have a wide range of possibilities ranging from activities with a low impact on environmental protection to comprehensive initiatives built with a long-term perspective and considering the organization's ecological responsibility [72].

The implementation of different sustainable strategies (Figure 1) is related to technological progress, which has provided a new ecological solution [18]. This shift has also forced companies to slowly withdraw from the so-called 'linear economy' approach [5]. The first strategies were characterized and named as 'end of pipe' technology-based solutions. These early strategies were based on the dilution of wastes and pollutions to meet the basic legal requirements for environment management imposed by the government [5,30]. To implement environmental strategy, energy producers' techniques dealt with emissions and were based on the limitation of pollution emission in uncomplicated processes.

Many companies invested significant amounts of money for environmental compliance [51]. The most important aspect for them was to increase process productivity [18]. Nowadays "it is considered that pollution and waste are a sign of low process efficiency" [5]. Therefore, electrical energy producers try to increase energy production effectiveness and implement clean production related to the proecological strategy.

Some companies from Standard and Poor's group involved in energy production [51], obtained a costly competitive advantage in a short time by reducing the emission of pollution [51]. Technological or process changes requires greater financial expenses than organizational shifts [51,73]. However, from a financial perspective [74], initial decrease of pollution yields the greatest results [51]. When the degree of emission approaches zero pollution, capital expenditures grow in a significant way. This is associated with an ever-deeper change within the organization. It is also necessary that the result of the main business process (product of service) is environmentally friendly. Then, the organization has both clean processes and clean products [57]. This includes a progressive change from process greening towards SSM [75].

Complementing one of the chosen sustainability strategy types should be the attitude of the whole company with aims toward SD. It is possible to specify strategy types due to the method of achieving harmony between the natural environment and organization or business environment $[26,58,63]$. Electrical energy producers often implement renewable energy technologies to diversify their energy production process and try to deliver more green electricity [65]. Such a change in power production is a result of the adopted type of sustainability strategy.

\subsection{Renewable Energy Sector in the V4}

Energy production in Central Europe is traditionally based on nonrenewable energy sources [76]. The V4 energy sector is historically rooted in fossil fuels, which occur abundantly in these countries, and among them are some of the biggest coal producers (Poland possesses the ninth largest coal deposits in the world). In electrical energy production in Central Europe, two major fuels are significant: hard coal and nuclear energy [77]. Changes in electrical production are moving towards more renewable energy in electricity production $[15,17,66]$. Therefore, the electrical energy generation subsystems in the Visegrád Group of countries is mixed and encompasses power plants, industrial power plants and heating plants, hydroelectric power plants, wind power, biomass and biogas [78]. Access to electrical energy is a criterion of wealth, as it determines economic and social development. Surprisingly, in the EU, the lowest rate of energy used per capita is achieved by Hungary (approx. 100 GJ per year) and Poland (approx. 115 GJ per year) [79,80]. It can be assumed that limited access to electricity determines the low wealth of a society and undermines the development of economies [81]. In the Visegrád Group of countries, there are active foreign 
investors and conventional energy producers who decided to develop their portfolios in the renewable energy sector. These investors are Axzon (biogas plants), Dalkia (biomass combustion), EDF, EDP Renewables, E.ON, GDF Suez (wind farms) and RWE, that along with the domestic companies are also investing in renewables [82].

In Czechia, primary electrical energy production is based on the use of fossil fuels [83]. The Czech Republic uses coal and lignite for approximately $47 \%$ of its electricity production and is second in Europe after Poland (73.6\%) [84]. Czechia was the fourth-biggest net electricity exporter in the EU in 2018, after France, Germany and Sweden [85]. However, the country's energy security is based on coal and lignite as conventional energy sources. Apart from coal (53\%), the country uses nuclear energy (35\%) and renewable energy (12\%) [86]. Czechia coal consumption records a decline in favor of biofuels, waste combustion and nuclear energy [87]. The largest electricity producer in Czechia is ČEZ (České Energetické Závody), and there are four much smaller producers: Severní Energetická, Sokolovská Uhelná, Elektrárny Opatovice and Teplárna Kladno. Electricity generation from renewables is driven by biogas, biomass, and solar (around 25\% each), followed by water energy (around 18\%). The remaining electricity production is covered by other RES, especially wind projects [87]. The fastest-growing renewable source of electricity in Czechia is photovoltaic power plants. The reason is the fall in the price of solar panels and the possibility of storing electricity. According to plans, by 2030 wind energy should cover one-third of electricity demand, whereas the development of biogas plants is subject to restrictions due to odors. Considering the various barriers that hinder the development of RES in Czechia, legislative restrictions are the most important [83].

In Hungary, the renewable energy sector has a small share in electricity generation and is dominated by biomass producers [80]. The energy sector in Hungary is mostly privatized, despite the largest company, MVM (Magyar Villamos Múvek) group being owned by the state [88]. In Hungary, conventional electricity generation comes mostly from nuclear $(49.3 \%)$ and coal $(8.5 \%)$, with natural gas contributing to nearly a quarter of the total electricity generated in Hungary in 2018 [89]. In Hungary, around 10\% of electricity production came from RES in 2018. Recognition that solar energy is particularly important for the development, means photovoltaic panels have been developed. The most important sources of renewable energy are solar energy and biomass, and wind energy has become much less important [90]. In Hungary, 4.5\% of renewable energy is produced, and electricity from renewable sources is mainly supplied by hydro and geothermal power plants [80].

In Poland, investments in renewable energy sources are developing rapidly despite regulatory barriers. The largest companies in Poland operating in the energy sector are PGE (Polska Grupa Energetyczna), Tauron, Enea, Energa and ZE PAK (Zespół Elektrowni Pątnów Adamów Konin). Therefore, the biggest renewable energy sector is constituted of listed electrical energy suppliers with Polish branches. The four key players the renewable energy market are PGE, Tauron, Enea and Energa [58]. Some changes influence the renewable energy sector development in this country. The geographic conditions favor wind power plants, but the majority of renewable energy is generated by hydropower plants [91]. Hydropower development is expected to be mainly based on the use of existing damming structures to produce electricity [92]. Another opportunity is favorable changes in law (prosumers energetics) that make more organizations and households interested in photovoltaic panels. This creates a new strategy, considering a for the prosumer client in the electricity generation processes [15]. In Poland, various sources of renewable energy do not play an important role in energy production [82]. The use of wind energy has developed little, while the use of solar energy is growing faster [93].

In Slovakia, the electricity market is relatively small compared to other EU countries [94]. Almost 55\% of energy production is supplied by nuclear power stations, $21 \%$ by conventional power stations, $14.4 \%$ by hydroelectric stations and $8.9 \%$ from other renewable sources [95]. Slovakia is considered one of the most energy-consuming economies in the EU countries [96]. In Slovakia, the major player in the electricity producer sector 
is Slovenské Elektrárne (SE). Slovakia is a relatively water-rich country, boasting many natural lakes, dams and rivers that support various water-intensive operations such as tourism, manufacturing and power generation [97]. Therefore, in Slovakia, hydropower is the most significant renewable energy source, accounting for around $40 \%$ of total energy production [95]. Geothermal waters and biomass plants are used to a small extent, while the possibilities of using solar energy, and thus solar panels and photovoltaic power plants, are growing [98].

A SWOT analysis (Figure 2) can be used in the RE sector to facilitate the selection and implementation of a sustainability strategy. Then, the results can be used to determine how strengths and development opportunities influence the process of achieving competitive advantage and reflect the sector's situation [99]. The analysis indicates weaknesses and threats which V4 countries have to eliminate or mitigate to provide better conditions for renewable energy organizations' development. Then, these organizations can project their strategy using strengths and opportunities, and avoid major problems [100]. Figure 2 presents the elements of the SWOT analysis for renewable energy sector industry development created by the electrical energy producers in V4 countries. The result of this analysis can be presented as similarities and differences.

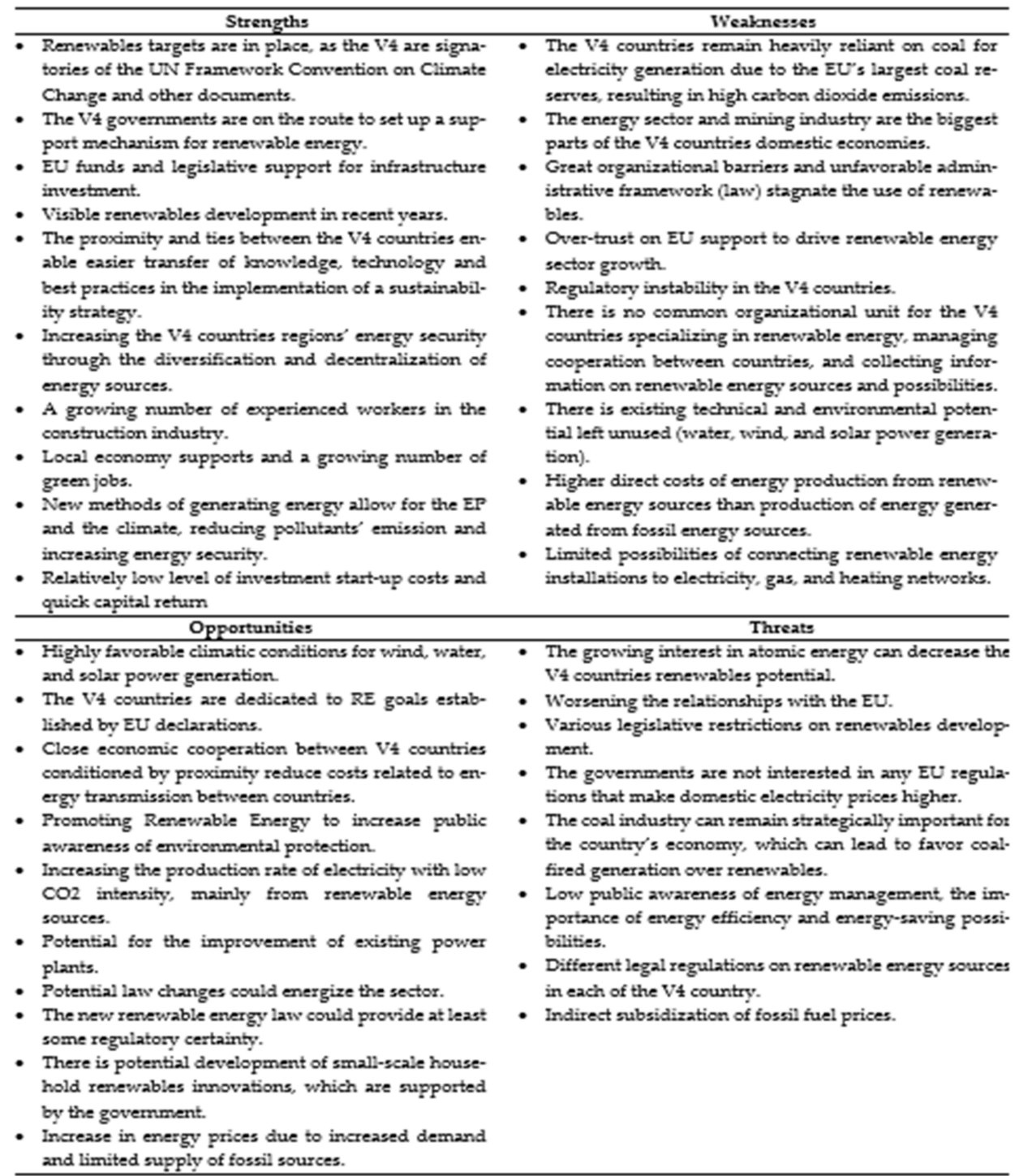

Figure 2. SWOT analysis of the V4 renewable energy sector. Author's elaboration based on [5]. 
Factors influencing the development of the RE sector and the directions of their impact on renewable energy producers were examined in the presented SWOT analysis. Similarities are identified among V4 countries, and each has developed some sustainability strategies [76]. What is more, among Visegrád Group countries, forecasting the future and planning in the long-term can improve the state of the environment in the next 10 or 20 years [6]. These have set their development goal to become carbon neutral by 2050. This eco-approach is promoted by the EU; therefore setting pro-eco policies may be motivated by the money offered by the EU for investments in the renewable energy sector [68]. All of the $\mathrm{V} 4$ countries are quickly improving their renewable energy industries, and their geographic locations and environmental conditions create good circumstances for increasing use of renewable energy [101]. The analysis presented in Figure 1 shows that there is a huge potential for the development of the renewable sector in the Visegrád Group. Development conditions for the V4 countries' renewable energy sources are convoluted and mainly rely more on external environmental factors than internal conditions.

One of the most important connections between these countries is membership in European Union. The EU's aims in terms of energy are clear. These objectives are reduction of $\mathrm{CO}_{2}$ emissions, development of renewable energy sources, an increase of efficiency and creation of a European energy market. Considering the EU's goals with the priorities of various sectors of the energy market will be a major threat for each of the V4 countries, especially since the objectives of the EU mean moving away from coal. This raises the question of the role of the mining industry in the future. There is an attempt to protect the mining industry by combining it with the energy industry, so that extraction costs of mining are reduced.

There are differences among the Visegrád Group countries in the renewable energy sector. For example, in Hungary and Czechia, the ecological awareness of residents and the willingness to implement proecological investments are growing, but this trend is less visible in Slovakia and Poland despite huge campaigns and education spending [77]. In Czechia, the renewable energy sector is divided almost equally between biogas, biomass, solar power and other types of renewable energy generation [6]. Contrasts are visible in various technologies used to achieve set goals for the renewable energy sector [1], and differences between them may result from different stages of the country's development or a different sustainability strategy implementation level [102]. The energy sector depends on the geographical location of the country, which results in differences between countries in adopting various energy generation technologies. For example, different climate conditions may either support or make renewable projects difficult or impossible to accomplish.

\section{Materials and Methods}

The subjects of the study were the main conventional energy produces in the Visegrád Group countries that decided to generate electrical energy from RES. This paper excludes nuclear energy as renewable energy; therefore, data related to this type of energy were not subject to analysis. Following the RE sector's transformation, the six energy producers emerged in the countries studied (Table 1). In Poland there are four main energy producers: PGE (Polska Grupa Energetyczna), Tauron, Energa and Enea. These companies have different characteristics related to RE generation, $\mathrm{CO}_{2}$ emissions, and shares in the electricity market in Poland. Unlike Poland, in the other Visegrád Group countries, there is only one main energy producer in each state. In Czechia the main producer of the energy is ČEZ (České Energetické Závody). In Slovakia it is SE (Slovenské Elektrárne), and in Hungary the main energy producer is MVM (Magyar Villamos Múvek). Besides these companies, there are foreign investors for both conventional and renewable energy producers, which market shares, but these are players in all V4 member states. All companies listed in Table 1 are the biggest energy producers and hold stakes in the Visegrád group's RE market [103]. The dominance of single organizations in Hungary, Slovakia, and Czechia is due to the fact that in these countries a significant amount of the electric energy is generated in nuclear power plants. The aim of this research was to research energy producers' sustainability strategies 
in the Visegrád Group countries. The common points of their sustainability strategies, based on the indicators for monitoring implementation, are listed in Table 1. The data were obtained from the companies' integrated reports. A quantitative research statistical reference method (the Hellwig's method) was implemented. The indicators presented in Table 1 were selected based on the Fitch Solutions reports [91].

Table 1. Basic indicators for monitoring the sustainability strategy in 2019.

\begin{tabular}{|c|c|c|c|c|c|c|c|c|}
\hline \multirow[b]{2}{*}{ Measured Characteristic } & \multirow[b]{2}{*}{ Symbol } & \multicolumn{7}{|c|}{ Company Name (Country Symbol) } \\
\hline & & $\begin{array}{l}\text { PGE } \\
(P L)\end{array}$ & $\begin{array}{c}\text { Tauron } \\
\text { (PL) }\end{array}$ & $\begin{array}{l}\text { Enea } \\
(P L)\end{array}$ & $\begin{array}{c}\text { Energa } \\
\text { (PL) }\end{array}$ & $\begin{array}{l}\text { CEZ } \\
(\mathrm{CZ})\end{array}$ & $\begin{array}{c}\text { SE } \\
(\mathrm{SK})\end{array}$ & $\begin{array}{c}\text { MVM } \\
\text { (HU) }\end{array}$ \\
\hline $\begin{array}{c}\text { Generation of electric energy from renewable } \\
\text { energy sources (TWh) }\end{array}$ & $\mathrm{x}_{1}$ & 1.7 & 1.4 & 2.3 & 1,4 & 15.4 & 16.8 & 16.4 \\
\hline Number of retail customers (millions) & $\mathrm{x}_{2}$ & 5.3 & 5.7 & 2.6 & 3,2 & 8.5 & 2.45 & 4.2 \\
\hline $\begin{array}{c}\text { Share of total domestic production of electric } \\
\text { energy }(\%)\end{array}$ & $x_{3}$ & 41.0 & 8.3 & 18.0 & 12.0 & 61.0 & 80.0 & 50.6 \\
\hline Renewable energy source installation power (MW) & $\mathrm{x}_{4}$ & 650.0 & 852.0 & 443 & 500 & 864.0 & 408.1 & 466.7 \\
\hline Annual volume of $\mathrm{CO}_{2}$ emissions ( $\mathrm{M}$ tons) & $x_{5}$ & 55.0 & 18.5 & 10.5 & 3.4 & 27 & 18.8 & 13.3 \\
\hline
\end{tabular}

Source: Authors' elaboration based on companies' integrated reports.

The reference method involves the determination of a synthetic variable being a function of the normalized features of the data input set. The essence of this method lies in a procedure according to which, from the explanatory variables in the matrix, a combination of variables is selected. Moreover, this method allows measurement and comparison of variables of different sizes and dimensions because a data standardization procedure is used. The purpose of the method is to compare the level of sustainability strategies among companies of the Visegrád Group countries that decided to produce electrical energy from RES. Indicators were defined by Eurostat [104] because their compatibility with the SDGs was accepted in the companies' reports. The variables used in calculations were assigned by the symbol $x$ with the number noted as a lower index. As a result, total number of five variables was determined in this way [58].

Secondary data from the year 2019 collected by the companies' integrated reports were used for the calculations, which ensured the comparability and reliability of the data. The reason for the choice of the reference method, especially the zero unitarization method [105], was the presentation of current sustainability strategies in the V4. Moreover, the application of the standard method allowed for the verification of the obtained results in the comparison with countries having similar development $[30,106]$, as described in the literature [107]. Since the set of independent characteristics contains variables that cannot be aggregated directly using appropriate standardization, normalization formulas were applied. Among the formulas, the method of zero unitarization was selected to standardize the process based on the interval of a normalized variable. Variables that positively influence the described phenomenon are called stimulants $\left(\mathrm{x}_{1}-\mathrm{x}_{4}\right)$. The only variable with the symbol $x_{5}$ is a destimulant. Indicators were selected for the standardization process based on the following formulas:

$$
\begin{gathered}
\text { for stimulants : } z_{i j}=\frac{x_{i j}-\min \left(x_{i j}\right)_{i}}{\max \left(x_{i j}\right)_{i}-\min \left(x_{i j}\right)_{i}} \\
\text { for de }- \text { stimulant : } z_{i j}=\frac{\max \left(x_{i j}\right)_{i}-x_{i j}}{\max \left(x_{i j}\right)_{i}-\min \left(x_{i j}\right)_{i}}
\end{gathered}
$$

where:

$z_{i j}$ is the normalized value of the $\mathrm{j}$-th variable in the $\mathrm{i}$-th country;

$x_{i j}$ is the initial value of the $\mathrm{j}$-th variable in the $\mathrm{i}$-th country. 
Diagnostic features normalized in this way take the value from the interval $(0 ; 1)$. The closer the value to unity, the better the situation in terms of the investigated feature; the closer the value to zero, the worse the situation.

In the next step, the normalized values of variables formed the basis for calculating the median and standard deviation for each of the countries studied. Median values were determined using the formulas:

$$
\begin{aligned}
& \text { for even numbers of observations : } M e_{i}=\frac{Z\left(\frac{m}{2}\right)_{i}+Z\left(\frac{m}{2}+1\right)_{i}}{2} \\
& \text { for odd numbers of observations : } M e_{i}=Z\left(\frac{m}{2}+1\right)_{i}
\end{aligned}
$$

where: $z_{i(j)}$ is the $\mathrm{j}$-th statistical ordinal for the vector $\left(Z_{i 1}, Z_{i 2}, \ldots, Z_{i m}\right), \mathrm{i}=1,2, \ldots, \mathrm{n} ; \mathrm{j}$ $=1,2, \ldots, \mathrm{m}$.

The standard deviation was calculated according to the following equation:

$$
S_{d i}=\sqrt{\frac{1}{m} \sum_{j=1}^{m}\left(z_{i j}-\overline{\mathrm{z}}\right)}
$$

Based on the median and standard deviation, an aggregate measure $w_{i}$ of the sustainability strategies was calculated for each country:

$$
w_{i}=M_{e i}\left(1-S_{d i}\right) ; w_{i}<1
$$

Values close to unity indicate a higher level of the sustainability strategy in the V4 member state, resulting in a higher rank. The aggregate measure places a higher rank on countries with a higher median of features describing the specific country, and those with a smaller differentiation between the values of features in the chosen state, as expressed by the value of the standard deviation [107]. The procedure selected for evaluating the sustainability strategy levels provided a multidimensional comparative analysis. Such an analysis allowed for a comparison between the Visegrad Group countries and grounds for classifying them into four groups (Table 2), where $\bar{w}$ is the mean value of the synthetic measure and $S$ is the standard deviation of the synthetic measure.

Table 2. Sustainability strategies aggregate measures comparative analysis.

\begin{tabular}{cccc}
\hline Group & $\begin{array}{c}\text { Mathematical } \\
\text { Characteristic }\end{array}$ & Meaning & Dominant Strategy \\
\hline I & $w_{i} \geq \bar{w}+S$ & high level & environmental excellence \\
II & $\bar{w}+S>w_{i} \geq \bar{w}$ & medium-high level & zero-waste strategy \\
III & $\bar{w} \geq w_{i} \geq \bar{w}-S$ & medium-low level & cleaner production strategy \\
IV & $w_{i}<\bar{w}-S$ & low level & 'end of pipe' \\
\hline Source: Authors' elaboration. & &
\end{tabular}

The biggest energy producers in the Visegrad Group countries play the main role in sustainability strategies in these countries. The differences between conventional energy producers who decided to generate energy from the RES reflect the disparities between the countries in which they operate.

\section{Results}

According to the calculated $w_{i}$ values, the V4 countries were assigned to one of the groups concerning their sustainability strategy level. In Table 3, the main energy producers from each country (countries symbols in brackets) are presented. 
Table 3. Results for the V4 countries main energy producers.

\begin{tabular}{ccccccc}
\hline \multirow{2}{*}{ Company Name (Country Symbol) } & \multicolumn{3}{c}{ Indicators' Symbols and Values } & \multicolumn{2}{c}{ Measure } \\
\cline { 2 - 7 } & $\mathbf{x}_{\mathbf{1}}$ & $\mathbf{x}_{\mathbf{2}}$ & $\mathbf{x}_{\mathbf{3}}$ & $\mathbf{x}_{\mathbf{4}}$ & $\mathbf{x}_{\mathbf{5}}$ & $\boldsymbol{w}_{\boldsymbol{i}}$ \\
\hline CEZ (CZ) & 54 & 8.5 & 61 & 864 & 27 & 0.64 \\
Tauron (PL) & 1.4 & 5.7 & 8.3 & 852 & 18.5 & 0.86 \\
PGE (PL) & 1.7 & 5.3 & 41 & 650 & 55 & 0.32 \\
Energa (PL) & 1.4 & 3.2 & 12 & 500 & 3.4 & 0.41 \\
MVM (HU) & 16.4 & 4.2 & 50.6 & 466.7 & 13.3 & 0.95 \\
Enea (PL) & 2.3 & 2.6 & 18 & 443 & 10.5 & 0.27 \\
SE (SK) & 16.8 & 2.5 & 80 & 408.1 & 18.8 & 0.37 \\
\hline Avg. value & 13.4 & 4.6 & 38.7 & 597.7 & 20.9 & 0.68 \\
Std. dev. & 19.2 & 2.1 & 27.1 & 193.6 & 16.7 & 0.20 \\
Var. Coeff. & 143.1 & 47.0 & 70.1 & 32.4 & 80.0 & 0.00 \\
\hline
\end{tabular}

Source: Authors' calculations.

The results presented in Table 3 show that the largest generation of electrical energy from RES in 2019 was in the Czech Republic, followed by Slovakia, Hungary and Poland. The number of retail customers is the highest in Poland, then in the Czech Republic, Hungary and Slovakia. The share of total domestic production of electrical energy has the highest percentage in Slovakia, followed by Poland (four companies contributed $79.3 \%$ in total), the Czech Republic and Hungary. Renewable energy source installation power is the highest in Poland (2445 MW in total), and lower in Czechia, Hungary, and Slovakia. On the other hand, the annual volume of $\mathrm{CO}_{2}$ emissions is the highest in Poland, then in Czechia, Slovakia and Hungary.

The analysis shows that there are countries in which main energy producers implement different sustainability strategy levels (Table 4).

Table 4. Groups of the V4 countries based on the main energy producers' strategies.

\begin{tabular}{ccc}
\hline Group & Countries & Values of $\boldsymbol{w}_{\boldsymbol{i}}$ for Countries \\
\hline I & Czechia (CZ) & 0.95 \\
II & Poland (PL) & $0.55^{*}$ \\
III & Hungary (HU) & 0.37 \\
IV & Slovakia (SK) & 0.27 \\
\hline
\end{tabular}

Source: Authors' calculations; ${ }^{*}$ calculated as an average value.

\section{Discussion}

The SWOT analysis presented in Figure 2 shows that there is potential for the future development of the RE sector in the Visegrád Group countries. Energy producers examined in this study belong to the Visegrád Group countries' states corporations. These organizations have common projects and cooperate with other renewable energy sector companies. Furthermore, favorable legislative changes (prosumer energetics) encourage a growing number of households' adoptions of renewable energy sources (e.g., photovoltaic panels). The role of the client in this process requires a change in strategy based on a new customer approach [108]. An evaluation of the sustainability strategy levels by measuring the effects of energy sector company indicators was based on the reference method [105], modified by the authors from its use in macroeconomic development research. A difficulty in analyzing the renewable energy sector in V4 countries is the deficit of harmonized data allowing comparison between countries and checking of the dynamics of changes over the years.

There are distinct tendencies that support growth of the RE sector in the Visegrád Group countries which are the largest beneficiaries of EU capital and support [91]. Many producers of electrical energy have implemented different levels of sustainability strategies because of growing ecological trends in business [5]. The multidimensional evolution of the strategies in the energy sector is shown in Table 5. Sustainability strategies in the RE producers' sector in the V4 countries are similar to the relationships presented in Figure 1, 
as in the third column showing sustainable strategies typology [109]. These strategies are a result of three pressure directions on the electrical energy producers. The first has a legal character, the second is the economic pressure of clients and the third is social opinion related to energy production hazards. However, changes in strategy are usually forced by external requirements imposed by legislation at the level of a country or a superior international organization. This external pressure is still applied, and it is even increased by the occurrence of environmental degradation.

Energy sector companies can choose between a broad spectrum of sustainable strategy levels (Table 5). There is a basic, minimum approach characterized by the organizations which implement the "end-of-pipe strategy" [51,110], which reflects the legal requirements for all companies. The "end of pipe" strategy refers to an environmental strategy characterized by isolation and a competition-oriented approach [111]. According to the Worthington's classification, there are other names for this approach, such as indifferent stage or defender position (organization self-defense) [57]. A characteristic feature from the point of view of implementing SDGs in the technological process is the occurrence of dirty processes and dirty products/services. The isolation strategy (minimum-level strategy) is based on minimalization of interactions between the natural environment and the organization (businesses environment) [112]. This strategy decreases the stability of the organizational system and is related to the limited interaction of the organization with the natural and business environment.

A cleaner-type production strategy can also be incorporated into the environmental strategy. Not paying attention to redundancy, organizations implement dirty processes but offer a clean product or service [108]. The redundancy strategy is based on maintaining access to various resources by the organization. These resources allow organizations to survive in crises and avoid short-term adaptation [113]. Due to access allowing restoration of stability at the interface between the organization and the environment, the system can operate in a partially independent manner, both from initial knowledge and the possibility of later obtaining reliable information about the environment. This strategy type encompasses proactive and crisis preventive approaches that stay in accordance with sustainable strategy topologies described by Worthington [57].

There is also the so-called "zero strategy" (also called the "no waste" strategy), which qualifies as the proecological strategy [57]. This strategy assumes an adaptive approach and implementation of clean processes and clean products/services. Adaptability is the potential for the organization to change itself or change its surrounding. This change allows at least some of the lost effectiveness to be regained.

Developing all the above-mentioned sustainable strategies leads to environmental excellence [114], or a green strategy. A green strategy is related to the natural environment, is built on SD and expresses greening of the organization. A green strategy assumes cooperation within the network. Then, the organization can obtain an environmental leadership position [57], not just a sustainable competitive advantage. The organization's technological process is optimal, as both the processes and products/services are clean.

In the literature, there are many sustainable strategy typologies, and the most common is the evolutionary one based on technological progress. This type of development is focused on better environmental protection. The authors of this paper extended a new classification of proecological strategies, as presented in Table 5. These multiple stages or types of sustainable strategies are considered in the strategic management literature. They vary between three and five elements; however the most popular consist of four levels [57]. According to the Hart classification, these are end-of-pipe, pollution prevention, product stewardship and sustainable development [115]. These levels are in accordance with the authors' proposition in Table 5. As listed by Worthington, four element stages or positions [57] are related to the findings of Verbke and Buysse [110]. 
Table 5. Strategies evolution-based classifications.

\begin{tabular}{|c|c|c|c|c|}
\hline Popular Name of the Strategy & Characteristic & Sustainability Strategy Types & $\begin{array}{c}\text { Sustainable Strategic } \\
\text { Management Approach and Focus } \\
\text { on Green Response }\end{array}$ & Strategy Model \\
\hline The "end of pipe" strategy & $\begin{array}{l}\text { The main aim of this strategy type is to } \\
\text { dilute or disperse all emissions to the } \\
\text { environment to be legally compliant, } \\
\text { but nothing more than simple treatment } \\
\text { is performed. }\end{array}$ & \multirow{2}{*}{ Environmental } & Isolation and Competition & $\begin{array}{l}\text { Dirty processes and dirty } \\
\text { products/services }\end{array}$ \\
\hline Cleaner production strategy & $\begin{array}{l}\text { The main objective of an organization is } \\
\text { to comply with the law because of } \\
\text { cleaner production and, if possible, to } \\
\text { treat but not eliminate wastes before the } \\
\text { end of the production cycle. }\end{array}$ & & Redundancy & $\begin{array}{c}\text { Dirty processes and clean } \\
\text { product/service }\end{array}$ \\
\hline $\begin{array}{l}\text { Zero waste strategy } \\
\text { No waste strategy }\end{array}$ & $\begin{array}{l}\text { This strategy aims to design a process } \\
\text { (production or service) to avoid } \\
\text { material losses, so all wastes are reused } \\
\text { or recycled. This strategy is ahead of the } \\
\text { law because it not only minimizes } \\
\text { emissions but also eliminates them. }\end{array}$ & Proecological & Adaptation & \multirow[b]{2}{*}{$\begin{array}{c}\text { Clean processes and clean } \\
\text { product/service }\end{array}$} \\
\hline $\begin{array}{l}\text { Green strategy } \\
\text { Environmental excellence strategy }\end{array}$ & $\begin{array}{l}\text { The basis for this strategy is a } \\
\text { conviction that other organizations can } \\
\text { use some wastes more effectively or } \\
\text { process them better, i.e., "someone's } \\
\text { trash is someone else's treasure". This } \\
\text { strategy aims to connect all supply } \\
\text { chains into a bigger ecosystem to allow } \\
\text { other organizations to use recovered } \\
\text { resources (previously seen as waste) in } \\
\text { their processes with new possibilities. }\end{array}$ & Green Strategy & Cooperation and Networking & \\
\hline
\end{tabular}




\section{Conclusions}

Even though the SD idea is 50 years old, it has developed more in theory than in practice. Lack of interest and skills in implementing the concept means that there are no measurable social, economic and environmental results. It may even be stated that since the 1970s, social, economic and ecological inequalities between countries and regions have deepened. Despite the declarations and implementation of proecological initiatives, companies' actions are chaotic and inconsistent.

In this paper, research on the RE producers' strategies is limited to the V4 group intentionally. It was assumed that due to historical, political, economic and geographical conditions, companies from these countries would operate in a similar business environment and conditions. This, however, limits research results to countries from the Visegrád Group, where we can make comparisons among countries at a similar level of development. In the study, we did not measure the degree of translation of the SDGs into the implementation of the strategy, and only chosen measures were compared, which means that the study focused on selected, comparable indicators reported by the energy producers in the renewable energy sector.

The novelty of this work covers several aspects presented in the research. The authors presented a new view on renewable energy producers' strategies in the Visegrád Group Countries. The starting point for the considerations was the theory of sustainable development and sustainable strategic management. The authors proposed a new concept of sustainability strategies for companies that can choose between an environmental strategy, a pro-ecological strategy, and a green strategy (Figure 1). Contribution to science is a factor in the strategy types that energy sector companies can choose. The authors highlighted the wide range of opportunities associated with different levels of energy support in environmental efforts, from end-of-pipe to environmental excellence (Table 5). The authors used a statistical reference method (Hellwig's method) based on data gained from the businesses. There are few similar types of research on renewable energy producers based on business data and calculated with Hellwig's method. Other authors using this method in different contexts usually based their studies on the administrative level comparisons and classifications into groups or ordering in ascending/descending orders.

This study contributes to sustainable strategic management (SSM), sustainability strategies and SDG research. The observations in this study were limited to the degree of implementation of SDGs, so future research is required in this area. Indicated problems result from inadequate SSM [49] and the lack of implementation of strategies. Therefore, it is not so much the strategy implementation declaration that matters, but the strategy implementation process. The selection of strategic goals that positively impact the environment is essential only when this is translated into the strategy implementation.

Concerning practical implications, one should pay attention to several problems. The need to transition electricity generation from fossil fuels to renewable energy sources should be reflected in the implementation of SDGs in energy producers' strategies. The use of electricity generated from fossil fuels depletes natural resources and degrades the environment. Despite declaring the intention to reduce energy demand, there is an increase in electricity consumption in the world, still obtained mainly from fossil fuels. This increase in demand for electricity is driven by economic development. Growing investments in the energy sector, and use of RES, can be seen as a way to achieve energy independence among Central European countries. Therefore, all Visegrád Group countries are strong proponents of the diversification of energy supplies and transit routes and try to enhance and support the energy sector transition. These countries are building mutual network connections to enhance the region's security and reduce the negative effects of one-sided dependency. Therefore, fossil fuel and "brown-based" international policy lead towards strong dependencies when renewable energy sources promise independence. All the initiatives of the Visegrád Group energy producers are aimed at supporting energy stability in the Central European region. There is development capacity for the renewable energy 
sector based on sustainable strategies within the SD movement, and there is also space for the greening the electricity producers by a green strategy.

Regarding social implications, it is worth paying attention to new opportunities related to shaping consumer behavior. Information about electricity producers' strategies can be an essential factor in influencing consumer choices. The growing requirements of customers as to the composition of products and production processes has been reflected in the creation of labels confirming compliance with social criteria. Similarly, consumers using electricity can decide on the choice of supplier, bearing in mind the company's commitment to respect for the natural environment and implementing sustainability strategies. Thus, consumers are able to find out about renewable strategies and make more aware of energy supplier choices.

The assessment of the RE sector development conditions leads to the conclusion that only the state can take the risk of the transformation of the energy sector towards greener and sustainable practices and based on RES. The reasons are the scale of the investments and regulations associated with energy production. The state is a major stakeholder, or owner, of the power plants, suppliers, and related distribution infrastructure which constitute the energy producer companies studied in this research. In this study, we encountered multiple misunderstandings, and false or unchecked information, in the reports of the energy sector in the Visegrád Group countries. The most reliable data used in our research were expensive reports, which, in our opinion, restrict important information for decision-making processes.

In the Visegrád Group topics related to the transition towards a green economy, such as aspects of electromobility, have gained attention in recent years. However, implementation is an illusion, since the majority of generated energy comes from nonrenewable resources. Only an increase in RES can reduce the emissions generated by energy-related economy sectors. The problem is that nuclear energy is considered safe and ecofriendly among the V4 societies, despite the hazards associated with it. In domestic statistics, this type of energy is also classified as renewable, which effectively changes the internal electricity market image of Slovakia, Czechia and Hungary.

An opposite approach is when organizations choose a green strategy that responds to legal requirements and results in the organizations adopting an active attitude towards environmental protection and management evident in green decisions. Changes in technology support changes in the proecological and green strategies in the natural environment. Organizations face the choice of various technological solutions related to the chosen organization's development strategy. On the other hand, technology allows protection of scarce resources and an open perspective for resource-based strategies. These green strategy-driven organizations do much more than required by law and their actions are not based on fear of penalties. Organizations that implement green strategies represent a type of strategic thinking that looks far into the future and translates their strategic goals into a specific management style that is consistent with a sustainability strategy level.

Developing the RE sector can not only reduce negative impacts and protect the natural environment, but it is also possible to act towards energy independence from big suppliers of energy providers and producers in the region [106]. The energy sector is especially involved in the economy because RES can impact prices of goods and services and shape wellbeing.

Accelerating the development of RE requires creating a new conceptual framework, where the basic tool for the usage of SDGs is the implementation of the strategy. We recognized the possibility of a future research direction dedicated to the SWOT analysis for each V4 country's electrical energy sector. To increase the effectiveness of strategy implementation, it is necessary to research the organization in the V4 group regarding difficulties related to the implementation of sustainability strategies. A possible research avenue is to study how to implement a corporate environmental strategy, or green strategy, and propose tools to measure this process. This can reveal possible new approaches to sustainability strategy level implementation related to the research presented in this paper. 
Such analysis can also open future research areas to examine development of strategies in the renewable energy sector.

Author Contributions: Conceptualization A.S. and L.S.-P.; methodology A.S. and L.S.-P.; formal analysis A.S. and L.S.-P.; investigation A.S. and L.S.-P.; writing-original draft preparation A.S., L.S.-P.; writing-review and editing A.S., L.S.-P.; visualization A.S., L.S.-P.; supervision A.S.; project administration, A.S., and L.S.-P.; funding acquisition, A.S., and L.S.-P. All authors have read and agreed to the published version of the manuscript.

Funding: (A.S.) The project is financed by the National Science Centre in Poland under the program "Business Ecosystem of the Environmental Goods and Services Sector in Poland", implemented in 2020-2022; project number 2019/33/N/HS4/02957; total funding amount PLN 120,900.00. (L.S.-P.) The project is financed by the Ministry of Science and Higher Education in Poland under the program "Regional Initiative of Excellence" 2019-2022; project number 015/RID/2018/19; total funding amount PLN 10,721,040.00.

Institutional Review Board Statement: Not applicable.

Informed Consent Statement: Not applicable.

Data Availability Statement: Not applicable.

Conflicts of Interest: The authors declare no conflict of interest. The funders had no role in the design of the study; in the collection, analyses, or interpretation of data; in the writing of the manuscript, or in the decision to publish the results.

\section{References}

1. Kozar, $€$. Energy sector and the challenges of sustainable development-Analysis of spatial differentiation of the situation in the EU based on selected indicators. Zesz. Nauk. SGGW Warszawie Probl. Rol. Swiat. 2019, 18, 173-186. [CrossRef]

2. Ferasso, M. The Environmental Impact of Economic Activities: The Case of the Five Economic Macroregions of the State of Santa Catarina/Brazil. Int. J. Environ. Sustain. Dev. 2007, 6, 436-450. [CrossRef]

3. Rubio-Mozos, E.; García-Muiña, F.E.; Fuentes-Moraleda, L. Sustainable strategic management model for hotel companies: A multi-stakeholder proposal to "walk the talk" toward SDGS. Sustainability 2020, 12, 8652. [CrossRef]

4. Barbosa, M.; Castañeda-Ayarza, J.A.; Lombardo Ferreira, D.H. Sustainable Strategic Management (GES): Sustainability in small business. J. Clean. Prod. 2020, 258. [CrossRef]

5. Sulich, A.; Grudziński, A. The analysis of strategy types of the renewable energy sector. In Proceedings of the Enterprise and Competitive Environment-22nd Annual International Conference, Chicago, IL, USA, 23-28 July 2000; Kapounek, S., Vránová, H., Eds.; Mendel University in Brno: Brno, Czech Republic, 2019; p. 59.

6. Chodkowska-Miszczuk, J.; Kulla, M.; Novotný, L. The role of energy policy in agricultural biogas energy production in Visegrad countries. Bull. Geogr. 2017, 35, 19-34. [CrossRef]

7. Derissen, S.; Quaas, M.F.; Baumgärtner, S. The relationship between resilience and sustainability of ecological-economic systems. Ecol. Econ. 2011, 70, 1121-1128. [CrossRef]

8. Lelek, L.; Kulczycka, J. Life cycle modelling of the impact of coal quality on emissions from energy generation. Energies 2020, 13, 1515. [CrossRef]

9. Wawrzyniak, D. $\mathrm{CO}_{2}$ emissions in the Visegrad Group countries and the European Union climate policy $\left[\mathrm{Emisja} \mathrm{CO}_{2} \mathrm{vw} \mathrm{krajach}\right.$ Grupy Wyszehradzkiej a polityka klimatyczna Unii Europejskiej]. Comp. Econ. Res. 2020, 23, 73-92. [CrossRef]

10. Muweis, J.; Łamasz, B. The development of the aviation fuel market in Poland and changes in civil passenger traffic. Polityka Energ. 2019, 22, 153-168. [CrossRef]

11. Bielecka, A.; Kulczycka, J. Coal combustion products management toward a circular economy-A case study of the coal power plant sector in Poland. Energies 2020, 13, 3603. [CrossRef]

12. Goodland, R.; Daly, H. Environmental Sustainability: Universal and Non-negotiable. Ecol. Appl. 1996, 6, 1002-1017. [CrossRef]

13. Szlávik, J.; Nagypál, N.C.; Pálvölgyi, T. Sustainability and business behaviour: The role of corporate social responsibility. Period. Polytech. Soc. Manag. Sci. 2005, 13, 93-105.

14. Kuriqi, A.; Pinheiro, A.N.; Sordo-Ward, A.; Bejarano, M.D.; Garrote, L. Ecological impacts of run-of-river hydropower plantsCurrent status and future prospects on the brink of energy transition. Renew. Sustain. Energy Rev. 2021, 142, 110833. [CrossRef]

15. Kath, C.; Nitka, W.; Serafin, T.; Weron, T.; Zaleski, P.; Weron, R. Balancing generation from renewable energy sources: Profitability of an energy trader. Energies 2020, 13, 205. [CrossRef]

16. Matláry, J.H. The European Union and the visegrad countries: The case of energy and environmental policies in Hungary. In Protecting the Periphery: Environmental Policy in Peripheral Regions of the European Union; Baker, S., Milton, K., Yearley, S., Eds.; Routledge: London, UK, 2019; pp. 136-152.

17. Du Pisani, J.A. Sustainable development-Historical roots of the concept. Environ. Sci. 2006, 3, 83-96. [CrossRef] 
18. Pupavac, D. Sustainable development-A new face of economy [Nachhaltige entwicklung—Ein neues gesicht der ökonomie]. Soc. Ekol. 2016, 24, 103-123. [CrossRef]

19. MVM. MVM Green Generation Limited Liability Company. Available online: http://mvm.hu/mvm-group/mvm-hungarowindwind-power-plant-operating-ltd/?lang=en (accessed on 8 March 2021).

20. PGE Energia Onawialna. Green Energy and Renewable Energy Sources (RES). Available online: https://pgeeo.pl/en/Zielonaenergia-i-OZE (accessed on 12 April 2021).

21. CEZ. Renewable Energy. Available online: https://www.cez.cz/en/cez-group/green-energy/renewable-energy (accessed on 8 April 2021).

22. Slovenské Elektrárne Renewables. Available online: https://www.seas.sk/renewables (accessed on 8 April 2021).

23. Sulich, A.; Sołoducho-Pelc, L.; Ferasso, M. Management Styles and Decision-Making: Pro-Ecological Strategy Approach. Sustainability 2021, 13, 1604. [CrossRef]

24. Lacko, R.; Hajduová, Z.; Zawada, M. The Efficiency of Circular Economies: A Comparison of Visegrád Group Countries. Energies 2021, 14, 1680. [CrossRef]

25. Wach, K.; Głodowska, A.; Maciejewski, M.; Sieja, M. Europeanization Processes of the EU Energy Policy in Visegrad Countries in the Years 2005-2018. Energies 2021, 14, 1802. [CrossRef]

26. Kuhlman, T.; Farrington, J. What is sustainability? Sustainability 2010, 2, 3436. [CrossRef]

27. Peters, J.; Simaens, A. Integrating sustainability into corporate strategy: A case study of the textile and clothing industry. Sustainability 2020, 12, 6125. [CrossRef]

28. Goodland, R. The concept of environmental sustainability. Annu. Rev. Ecol. Syst. 1995, 26, 1-24. [CrossRef]

29. Moldan, B.; Janoušková, S.; Hák, T. How to understand and measure environmental sustainability: Indicators and targets. Ecol. Indic. 2012, 17, 4-13. [CrossRef]

30. Sulich, A. The Green Economy Development Factors. In Proceedings of the 32nd International Business Information Management Association Conference (IBIMA), Seville, Spain, 15-16 November 2018; pp. 6861-6869.

31. Rutkowska, M.; Sulich, A. Green Jobs on the background of Industry 4.0. In Proceedings of the Procedia Computer Science, Virtual, 16-18 November 2020; Volume 176, pp. 1231-1240.

32. Duić, N.; Urbaniec, K.; Huisingh, D. Components and structures of the pillars of sustainability. J. Clean. Prod. 2015, 88, 1-12. [CrossRef]

33. Branzei, O.; Ursacki-Bryant, T.J.; Vertinsky, I.; Zhang, W. The formation of green strategies in Chinese firms. Startegic Manag. J. 2004, 25, 1075-1095.

34. Smol, M.; Kulczycka, J.; Avdiushchenko, A. Circular economy indicators in relation to eco-innovation in European regions. Clean Technol. Environ. Policy 2017. [CrossRef]

35. Lelek, L.; Kulczycka, J.; Lewandowska, A.; Zarebska, J. Life cycle assessment of energy generation in Poland. Int. J. Life Cycle Assess. 2016, 21, 1-14. [CrossRef]

36. Barbier, E.B. The Concept of Sustainable Economic Development. Environ. Conserv. 1987, 14, 101-110. [CrossRef]

37. Barbier, E.B. Green economy and sustainable development: Economic policy issues [Économie verte et développement durable: Enjeux de politique économique]. Reflets Perspect. Vie Économique 2012, 51, 97. [CrossRef]

38. Piwowar, A.; Dzikuć, M. Development of renewable energy sources in the context of threats resulting from low-altitude emissions in Rural Areas in Poland: A review. Energies 2019, 12, 3558. [CrossRef]

39. Bieker, T.; Gminder, C. Towards a Sustainability Balanced Scorecard: Linking environmental and social sustainability to business strategy. In Proceedings of the Conference Proceedings of Business Strategy and Environment, University of St. Gallen, Switzerland, 27-31 August 2001; ERP Environment Leads; ERP Environment, 2001. Available online: http:/ / www.oikos-stiftung. unisg.ch/academy2001/Paper_Bieker_Gminder.pdf (accessed on 27 August 2020).

40. Baumgartner, R.J.; Rauter, R. Strategic perspectives of corporate sustainability management to develop a sustainable organization. J. Clean. Prod. 2017, 140, 81-92. [CrossRef]

41. Suriyankietkaew, S.; Petison, P. A retrospective and foresight: Bibliometric review of international research on strategic management for sustainability, 1991-2019. Sustainability 2020, 12, 91. [CrossRef]

42. Stead, J.G.; Stead, W.E. Sustainable strategic management: An evolutionary perspective. Int. J. Sustain. Strateg. Manag. 2008, 1, 62. [CrossRef]

43. Sołoducho-Pelc, L.; Sulich, A. Between Sustainable and Temporary Competitive Advantages in the Unstable Business Environment. Sustainability 2020, 12, 8832. [CrossRef]

44. Piwowar-Sulej, K. Types of Organizational Culture in the context of Project Management Methodologies. In Proceedings of the Education Excellence and Innovation Management: A 2025 Vision to Sustain Economic Development during Global Challenges, Seville, Spain, 1-2 April 2020; Soliman, K.S., Ed.; Curran Associates, Inc.: Red Hook, NY, USA, 2020; pp. $1160-1171$.

45. Zapletalová, V.; Komínková, M. Who is fighting against the EU's energy and climate policy in the European Parliament? The contribution of the Visegrad Group. Energy Policy 2020, 139. [CrossRef]

46. Piwowar-Sulej, K. Human resources development as an element of sustainable HRM-With the focus on production engineers. J. Clean. Prod. 2021, 278. [CrossRef]

47. Porter, M.E. Towards a Dynamic Theory of Strategy. Strateg. Manag. J. 1991, 12, 95-117. [CrossRef]

48. Demil, B.; Lecocq, X. Business model evolution: In search of dynamic consistency. Long Range Plann. 2010, 43, 227-246. [CrossRef] 
49. Szymczyk, K. Towards sustainable strategic management: A theoretical rev evolution of management perception. Res. World Econ. 2019, 10, 58-64. [CrossRef]

50. Farias, G.; Farias, C.; Krysa, I.; Harmon, J. Sustainability Mindsets for Strategic Management: Lifting the Yoke of the Neo-Classical Economic Perspective. Sustainability 2020, 12, 6977. [CrossRef]

51. Hart, S.L.; Ahuja, G.; Arbor, A. Does it to pay to be green? An empirical examination of the relationship between emission reduction and firm performance. Bus. Strategy Environ. 1996, 5, 30-37. [CrossRef]

52. Baiardi, D. Do sustainable energy policies matter for reducing air pollution? Energy Policy 2020, 140. [CrossRef]

53. Lloret, A. Modeling corporate sustainability strategy. J. Bus. Res. 2016, 69, 418-425. [CrossRef]

54. Barnett, M.L.; Darnall, N.; Husted, B.W. Sustainability strategy in constrained economic times. Long Range Plann. 2015, 48, 63-68. [CrossRef]

55. Sofia, D.; Gioiella, F.; Lotrecchiano, N.; Giuliano, A. Mitigation strategies for reducing air pollution. Environ. Sci. Pollut. Res. 2020, 27, 19226-19235. [CrossRef] [PubMed]

56. Laszlo, C.; Cooperrider, D.; Fry, R. Global challenges as opportunity to transform business for good. Sustainability 2020, $12,8053$. [CrossRef]

57. Worthington, I. Greening Business; Oxford University Press: Oxford, UK, 2013.

58. Sulich, A.; Grudziński, A. The analysis of strategy types of the renewable energy sector. Acta Univ. Agric. Silvic. Mendel. Brun. 2019, 67, 1643-1651. [CrossRef]

59. Sulich, A.; Zema, T. Green jobs, a new measure of public management and sustainable development. Eur. J. Environ. Sci. 2018, 8 , 69-75. [CrossRef]

60. Wiśniewska, A. Pro-Ecological Strategies in Enterprise Management [Strategie Proekologiczne w Zarządzaniu Przedsiębiorstwem]. In Studia Ekologiczno-Krajobrazowe w Programowaniu Rozwoju Zrównoważonego. Przegląd Polskich Doświadczeń u Progu Integracji z Unia Europejska [Ecological Studies in Programming Sustainable Development. Review of Polish Experiences in UE accession]; Kistowski, M., Ed.; Europe Comission: Gdańsk, Poland, 2004; pp. 91-98.

61. Sobczak, E.; Bartniczak, B.; Raszkowski, A. Implementation of the no poverty sustainable development goal (SDG) in Visegrad Group (V4). Sustainability 2021, 13, 1030. [CrossRef]

62. Grudziński, A.; Sulich, A. Strategic goals of renewable energy sector. In Proceedings of the 16th Students' Science Conference, Science is Our Universe; Wodo, W., Sulich, A., Eds.; Wrocław University of Science and Technology: Wrocław, Poland, 2018 ; pp. 36-44.

63. Aarstad, J.; Jakobsen, S.E. Norwegian firms' green and new industry strategies: A dual challenge. Sustainability 2020, $12,361$. [CrossRef]

64. Chodkowska-Miszczuk, J.; Martinat, S.; Kulla, M.; Novotný, L. Renewables projects in peripheries: Determinants, challenges and perspectives of biogas plants-Insights from Central European countries. Reg. Stud. Reg. Sci. 2020, 7, 362-381. [CrossRef]

65. Janeiro, L.; Resch, G. Renewable Energy Target Realisation Forecast for Poland. 2020. Available online: http://psew.pl/ en/wp-content/uploads/sites/2/2017/04/2020-Renewable-Energy-Target-Realisation-Forecast-for-Poland.pdf (accessed on 2 February 2021).

66. Marques, A.C.; Fuinhas, J.A.; Pires Manso, J.R. Motivations driving renewable energy in European countries: A panel data approach. Energy Policy 2010, 38, 6877-6885. [CrossRef]

67. Nagypál, N.C. Corporate social responsibility of hungarian SMEs with good environmental practices. J. East. Eur. Manag. Stud. 2014, 19, 327-347. [CrossRef]

68. Töro, C.; Butler, E.; Grúber, K. Visegrád: The Evolving Pattern of Coordination and Partnership After EU Enlargement. Eur. Asia Stud. 2014, 66, 364-393. [CrossRef]

69. Sviteková, M.; Pavolová, H.; Hlavňova, B. An energy strategy in a liberalized environment in Slovakia. In Progress in Sustainable Energy Technologies Vol II: Creating Sustainable Development; Springer International Publishing: Cham, Switzerland, 2014; pp. 347-368.

70. Antoni-Komar, I.; Beermann, M.; Schattke, H. Additional challenges for CEMIS due to impacts caused by climate change. In Corporate Environmental Management Information Systems: Advancements and Trends; IGI Global: Hershey, PA, USA, 2010; pp. 70-84.

71. Doczi, G. The Power of limits_-Proportional Harmonies in Nature, Art, and Architecture; Shambhala Publications: Berkeley, CA, USA, 1999; pp. 201-223. ISBN 9781590302590.

72. Málovics, G.; Csigéné, N.N.; Kraus, S. The role of corporate social responsibility in strong sustainability. J. Socio. Econ. 2008, 37, 907-918. [CrossRef]

73. Loiseau, E.; Saikku, L.; Antikainen, R.; Droste, N.; Hansjürgens, B.; Pitkänen, K.; Leskinen, P.; Kuikman, P.; Thomsen, M. Green economy and related concepts: An overview. J. Clean. Prod. 2016, 139. [CrossRef]

74. Ambec, S.; Lanoie, P. Does it pay to be green? A systematic overview. Acad. Manag. Perspect. 2008, 22, 45-62. [CrossRef]

75. Bartek-Lesi, M.; Dézsi, B.; Diallo, A.; Szabó, L. András Mezősi Auctions for the Support of Renewable Energy in Hungary: Main Results and Lessons Learnt. Available online: http:/ / aures2project.eu/2020/02/05/auctions-for-the-support-of-renewableenergy-in-germany/ (accessed on 23 May 2021).

76. Rokicki, T.; Perkowska, A. Changes in energy supplies in the countries of the Visegrad Group. Sustainability 2020, $12,7916$. [CrossRef]

77. Magda, R.; Bozsik, N.; Meyer, N. An Evaluation of Gross Island Energy Consumption of Six Central European Countries. J. East. Eur. Cent. Asian Res. 2019, 6. [CrossRef] 
78. Šupín, M.; Kaputa, V.; Parobek, J. Wood biomass as a renewable resources market development in the EU. In Proceedings of the Scientific Papers More Wood Better Management Increasing Effectiveness: Starting Points and Perspective, Prague, Czech Republic, 24-26 May 2017; pp. 25-32.

79. Eurostat. Energy, Transport and Environment Statistics 2019 Edition. Available online: https: / / ec.europa.eu/eurostat/about/ policies/copyright (accessed on 13 April 2021).

80. OECD. Hungary. Available online: http://stats.oecd.org/wbos/fileview2.aspx?IDFile=37348365--0442--4dd3--8d38--706eb3ad2 dfa (accessed on 14 May 2021).

81. Kanagawa, M.; Nakata, T. Assessment of access to electricity and the socio-economic impacts in rural areas of developing countries. Energy Policy 2008, 36, 2016-2029. [CrossRef]

82. Polish Investement and Trade Agency [Polska Agencja Inwestycji i Handlu]. Renewable Energy. Available online: https: / / www.paih.gov.pl/sectors/renewable_energy\# (accessed on 14 April 2021).

83. Pokorná, V. Renewable Energy Potential in the Czech. Republic: Obstacles to Achieve It; Europeum: Europeum, Czech Republic, 2018.

84. The Polish Institute of International Affairs [Polski Instytut Spraw Miedzynarodowych]. The Czech Republic in the Process of Climate and Energy Transformation [Czechy w Procesie Transformacji Klimatyczno-Energetycznej]. Available online: https: //www.pism.pl/publikacje/Czechy_w_procesie_transformacji_klimatycznoenergetycznej (accessed on 9 March 2021).

85. Mammadli, G. The Energy industry in the Czech Republic. Available online: https://www.yeyeagency.com/energy-industry-inthe-czech-republic/ (accessed on 12 April 2021).

86. Mordor Intelligence. Czech Republic Renewable Energy Market—Segmented by Type—Growth, Trends, COVID-19 Impact, and Forecasts (2021-2026). Available online: https:/ / www.mordorintelligence.com/industry-reports/czech-republic-renewableenergy-market (accessed on 14 May 2021).

87. CMS. Renewable Energy Law and Regulation in Czech Republic. Available online: https://cms.law/en/int/expert-guides/cmsexpert-guide-to-renewable-energy/czech-republic (accessed on 14 May 2021).

88. Hungarian Ministry of National Development. Renewable Energy: Republic of Hungary National Renewable Action Plan. 2010-2020; Hungarian Ministry of National Development: Budapest, Hungary, 2010. Available online: https://2010-2014.kormany.hu/ download/6/b9/30000/RENEWABLE\%20ENERGY_REPUBLIC\%20OF\%20HUNGARY\%20NATIONAL\%20RENEWABLE\% 20ENERGY\%20ACTION\%20PLAN\%202010_2020.pdf (accessed on 14 March 2021).

89. Enerdata Energy Market Research in Hungary. Available online: https:/ / www.enerdata.net/estore/country-profiles/hungary. html (accessed on 13 April 2021).

90. ABO Wind. Hungary KFT Hungary. Available online: https://www.abo-wind.com/en/the-company/international/hungary. html (accessed on 13 April 2021).

91. Fitch Solutions. Poland Renewables Report, Q4 2018; Fitch Solutions: New York, NY, USA, 2018.

92. Kowalczyk, M. Survey of Damming Structures. In Proceedings of the Today and Tomorrow of Hydropower in Poland and the EU Conference, RENEXPO, Augsburg, Germany, 27-30 September 2012; KZGW: Warszawa, Poland, 2012.

93. ABO Wind. Hungary KFT Poland. Available online: https://www.abo-wind.com/en/the-company/international/poland.html (accessed on 13 April 2021).

94. Brozyna, J.; Strielkowski, W.; Fomina, A.; Nikitina, N. Renewable energy and EU 2020 target for energy efficiency in the Czech Republic and Slovakia. Energies 2020, 13, 965. [CrossRef]

95. International Trade Administration. Slovakia-Renewable Energy. Available online: https://www.trade.gov/energy-resourceguide-slovakia-renewable-energy (accessed on 14 May 2021).

96. Slovenské Elektrárne. Energetika na Slovensku. Available online: https:/ / www.seas.sk/energetika-na-slovensku (accessed on 13 April 2021).

97. Credit Risk Monitor. Slovakia Utilities Network Analysis. Available online: https://info.creditriskmonitor.com/NewsStory.aspx? NewsId=26813794\&rc=W0OLA1K8RW1DW20UXZ (accessed on 14 May 2021).

98. International Trade Administration. Slovakia Renewable Energy. Market Intelligence. 2021. Available online: https://www.trade. gov / market-intelligence/slovakia-renewable-energy (accessed on 23 May 2021).

99. Azzone, G.; Bertelè, U. Exploiting green strategies for competitive advantage. Long Range Plann. 1994, 27, 69-81. [CrossRef]

100. Rokicki, T.; Perkowska, A. Diversity and Changes in the Energy Balance in EU Countries. Energies 2021, 14, 1098. [CrossRef]

101. Kotulewicz-Wisińska, K. Participation of the Visegrad Group countries in the implementation of the Eastern Partnership programme. Sovrem. Evr. 2018, 96-107. [CrossRef]

102. Us, Y.; Pimonenko, T.; Lyulyov, O. Energy efficiency profiles in developing the free-carbon economy: On the example of Ukraine and the V4 countries. Polityka Energ. 2021, 23, 49-66. [CrossRef]

103. Gorczyca, M. Energy from renewable sources in Poland compared to other European Union countries [Energia ze źródełodnawialnych w Polsce na tle innych krajów Unii Europejskiej]. Energ. Ekol. 2011, 515-518. Available online: https: / / elektroenergetyka.pl/upload/file/2011/8/Gorczyca.pdf (accessed on 12 April 2021).

104. Eurostat. Tables on EU policy_Circular Economy. Available online: https:/ / ec.europa.eu/eurostat/web/circular-economy/ indicators / main-tables (accessed on 16 March 2021).

105. Hellwig, Z. Application of the Taxonomic Method to the Countries Typology according to their Level of Development and the Structure of Resources and Qualified Staff. Przeglad Stat. 1968, 307-326. 
106. Ludvig, Z. The enlarged EU and Russia-What do Visegrad-countries contribute to EU-Russian economic relationship? J. East.West. Bus. 2005, 11, 67-92. [CrossRef]

107. Kasztelan, A. Green Competitiveness of the EU Countries. In Proceedings of the 3rd International Conference on European Integration, Ostrava, Czech Republic, 19-20 May 2016; Kovářová, E., Melecký, L., Staníčková, M., Eds.; VŠB-Technical University of Ostrava: Ostrava, Poland, 2016; pp. 415-424.

108. Zaleski, P. The Renwable Energy Sources development perspective in Poland [Perspektywa rozwoju Odnawialnych ŹródełEnergii w Polsce]. Nowa Energ. 2015, 5/6, 24-27.

109. Roome, N. Business Startegy, Researrch and Development Management and Environmental Imperatives. RED Manag. 1994, 24, 65-82. [CrossRef]

110. Verbeke, A.; Buysse, K. Proactive environmental strategies: Astakeholder management perspective. Strateg. Manag. J. 2003, 24, 453-470.

111. Igliński, B. Research on the Renewable Energy Sector in Poland-Technical Potential, PEST Analysis [Badanie Sektora Energii Odnawialnej w Polsce-Potencjał Techniczny, Analiza PEST]; Wydawnictwo Naukowe Uniwersytetu Mikołaja Kopernika: Toruń, Poland, 2020; ISBN 9788323143109.

112. Wirth, H.; Kulczycka, J.; Hausner, J.; Koński, M. Corporate Social Responsibility: Communication about social and environmental disclosure by large and small copper mining companies. Resour. Policy 2016, 49, 53-60. [CrossRef]

113. Ikram, M.; Zhang, Q.; Sroufe, R. Developing integrated management systems using an AHP-Fuzzy VIKOR approach. Bus. Strateg. Environ. 2020, 29, 2265-2283. [CrossRef]

114. Roome, N. Developing environmental management strategies. Bus. Strateg. Environ. 1992, 1, 11-24. [CrossRef]

115. Hart, S.L. Beyond Greening: Strategies for a Sustainable World'. Harv. Bus. Rev. 1997, 75, 66-76.

116. Lee, S.Y.; Rhee, S. The change in corporate environmental strategies: A longitudinal empirical study. Manag. Decis. 2007, 45, 196-216. [CrossRef] 